\title{
The Influence of Organomineral Fertilizers on the Growth of Seedlings of Scotch Pine
}

\author{
J. M. Juraev \\ Ugam Chatkal State Natural National Garden, Sidjjak Branch Office of Birchmulla state forestry
}

In our country usage of various types of fertilizers into soil is one of efficient methods of intensification of forestry. Lately fertilizers were mainly used for growing of deciduous trees seedlings in creating of shelterbelt afforestations (T.A.Zheltikova, 1965, S.K.Kojahmetov, 1995) at the same time it is necessary to take into account annual norms in meeting demands of national economy in woodworking industry and landscape and shade gardening. To achieve these it is necessary to grow highly qualitative seedlings of coniferous kinds of trees and also to solve the problem of raising Scotch pine seedlings in nurseries at foothill conditions.

The latest research works, in contradiction to former thoughts, showed that nutrients are necessary in a great quantity for seedlings and forest trees grown from seeds. Meanwhile, every year in digging up of seedlings nearly full nutrient are go out together with them. From one side it is proved that forest plants need a great quantity of nutrients.

Our research consists of working out of efficient terms and quantity of organic and mineral fertilizers with the purpose of obtaining seedlings from nurseries planted by Scotch pine with the least expenditure of capitals.

The research was carried out at Sijjak branch of Brichmula forestry. Soil-cinnamonic calcareous, there are till 1,73-2,80 $\%$ of humus, till 0,180-0,196 \% of nitrogen and 0,163-0,168 $\%$ of phosphorus in the layer (thickness $0-30 \mathrm{~cm}$ ). This soil is poor for content of easy available nutrients. The quantity of nitrate makes 7,1-10,0 mg, available phosphorus - 15,226,0 mg per kilogram of soil.

Experiments were conducted on the following variants of terms and norms of organic and mineral fertilizers application.

1) Control (without fertilizer);

2) Manure $20 \mathrm{t} / \mathrm{ha}$ - before sowing;

3) N60P30 - before sowing;

4) N60P30+20 t/ha of common manure before sowing;

5) N90P60K30 - N60P30K30 before planting, the rest N30P30 - nourishing at the beginning of height growth period;

6) N120P90K30 - N60P30K30 before sowing, the rest N30P30 were fed at the initial and maximal height growth periods.

Before sowing seeds the soil was deeply tilled and leveled. The seeds were sown in the quantity of $3,5 \mathrm{gr}$. per linear meter and imbedded at 1,5-2 cm depth. Rotten humus was poured at the top of sown seeds by thickness $1-1,5 \mathrm{~cm}$. Germination of seeds were always calculated by 1linear meter.

Seeds of Scotch pine were sown on 3 June, rare seedlings on 10 June, and totally they appear on 15 June.

As seen from table 1 data, organic and mineral fertilizers showed positive influence on the growth of 1-year-old Scotch pine seedlings.

Table 1: The influence of organomineral fertilizers on growth of 1 year old Scotch pine seedlings

\begin{tabular}{|c|c|c|c|c|c|c|c|c|}
\hline \multirow[t]{2}{*}{ Variants } & \multicolumn{2}{|c|}{ Height } & \multirow{2}{*}{$\begin{array}{c}\text { Diameter of root } \\
\text { neck, } \mathrm{cm}\end{array}$} & \multicolumn{2}{|c|}{ Length of root } & \multicolumn{2}{|c|}{ Dry mass } & \multirow{2}{*}{$\begin{array}{l}\text { Degree of reliability of } \\
\text { experiment, } \%\end{array}$} \\
\hline & $\mathrm{cm}$ & $\%$ & & $\mathrm{~cm}$ & $\%$ & gr & $\%$ & \\
\hline Control(without fertilizer) & $5,07 \pm 0,13$ & 100 & 0,10 & $16,3 \pm 0,64$ & 100 & 3,45 & 100 & 2,6 \\
\hline Manure -20 t/ha & $6,22 \pm 0,23$ & 122,6 & 0,10 & $17,8 \pm 1,0$ & 109,1 & 5,15 & 149,2 & 3,8 \\
\hline $\mathrm{N}_{60} \mathrm{P}_{30}$ & $5,90 \pm 0,17$ & 116,4 & 0,11 & $16,3 \pm 0,64$ & 100 & 4,99 & 144,6 & 2,9 \\
\hline $\mathrm{N}_{60} \mathrm{P}_{30}+$ manure $20 \mathrm{t} / \mathrm{ha}$ & $6,70 \pm 0,16$ & 132,1 & 0,12 & $16,0 \pm 0,67$ & 100 & 6,40 & 185,5 & 2,4 \\
\hline $\mathrm{N}_{90} \mathrm{P}_{60} \mathrm{~K}_{30}$ & $6,30 \pm 0,13$ & 124,1 & 0,13 & $16,0 \pm 0,69$ & 100 & 7,55 & 218,8 & 3,6 \\
\hline $\mathrm{N}_{120} \mathrm{P}_{90} \mathrm{~K}_{30}$ & $7,00 \pm 0,30$ & & & $17,5 \pm 0,70$ & & 8,20 & & 3,0 \\
\hline
\end{tabular}

N60P30 variant the height of seedlings were for $16,4 \%$ higher in comparison with control one, the amount of dry substances was higher for 44,6\%. In variant N90P60K30 the growth was high for $24,1 \%$ and dry substance was more for 2,1 times in comparison with control one. In the variant
N60P30+20 $\mathrm{t} /$ ha of added manure the growth was high for $32,1 \%$ and dry mass was increased for $-85,5 \%$ in comparison with control one, when only manure was added, it was $22,6 \%$ and $49,1 \%$ respectively. Two years old seedlings grew better in variants with fertilizers. (table 2 ). 


\section{International Journal of Science and Research (IJSR) \\ ISSN (Online): 2319-7064}

Index Copernicus Value (2016): 79.57 | Impact Factor (2015): 6.391

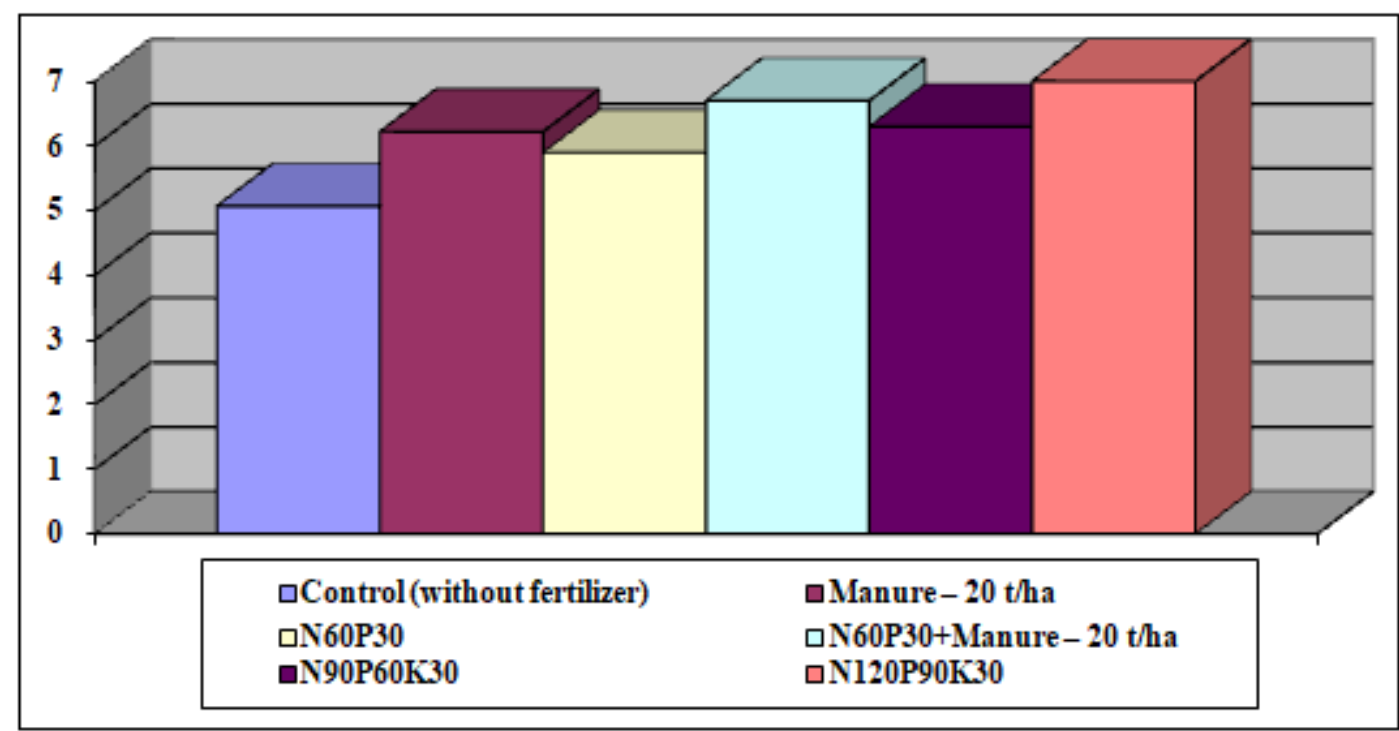

Figure 1: The influence of organo-mineral fertilizers on growth of the height of 1-year-old Scotch pine seedlings, $\mathrm{cm}$

Table 2: Indexes of 2 years old seedlings of Scotch pine

\begin{tabular}{|c|c|c|c|c|c|c|c|c|}
\hline \multirow{2}{*}{ Variants } & \multicolumn{2}{|c|}{ Height } & Diameter of & \multicolumn{2}{c|}{ Length of root } & \multicolumn{2}{c|}{ Dry mass } & Degree of reliability \\
& $\mathrm{cm}$ & $\%$ & root neck, cm & $\mathrm{cm}$ & $\%$ & $\mathrm{gr}$ & $\%$ & of experiment, $\%$ \\
\hline Control(without fertilizer) & $5,07 \pm 0,13$ & 100 & 0,10 & $16,3 \pm 0,64$ & 100 & 3,45 & 100 & 2,6 \\
\hline Manure - 20 t/ha & $6,22 \pm 0,23$ & 122,6 & 0,10 & $17,8 \pm 1,0$ & 109,1 & 5,15 & 149,2 & 3,8 \\
\hline $\mathrm{N}_{60} \mathrm{P}_{30}$ & $5,90 \pm 0,17$ & 116,4 & 0,11 & $16,3 \pm 0,64$ & 100 & 4,99 & 144,6 & 2,9 \\
\hline $\mathrm{N}_{60} \mathrm{P}_{30}+$ manure 20 t/ha & $6,70 \pm 0,16$ & 132,1 & 0,12 & $16,0 \pm 0,67$ & 100 & 6,40 & 185,5 & 2,4 \\
\hline $\mathrm{N}_{90} \mathrm{P}_{60} \mathrm{~K}_{30}$ & $6,30 \pm 0,13$ & 124,1 & 0,13 & $16,0 \pm 0,69$ & 100 & 7,55 & 218,8 & 3,6 \\
\hline $\mathrm{N}_{120} \mathrm{P}_{90} \mathrm{~K}_{30}$ & $7,00 \pm 0,30$ & & & $17,5 \pm 0,70$ & & 8,20 & & 3,0 \\
\hline
\end{tabular}

As seen from table 2 data, in variants N90P60K30 and N120P90K30 growth was high for 33,3 - 38,0 \% and diameter of root neck for $38,4 \%$ in comparison with control variant. In variants where fertilizers were fully added, dry substances were more concentrated. For example, in variants N90P60K30 and N120P90K30 dry mass in seedlings of 2 years old Scotch pine increased from 40,0 gr till 70,2 - 75,4 gr. In variants, where manure separately and manure with mineral fertilizers were added, showed positive influence on accumulation of dry mass.

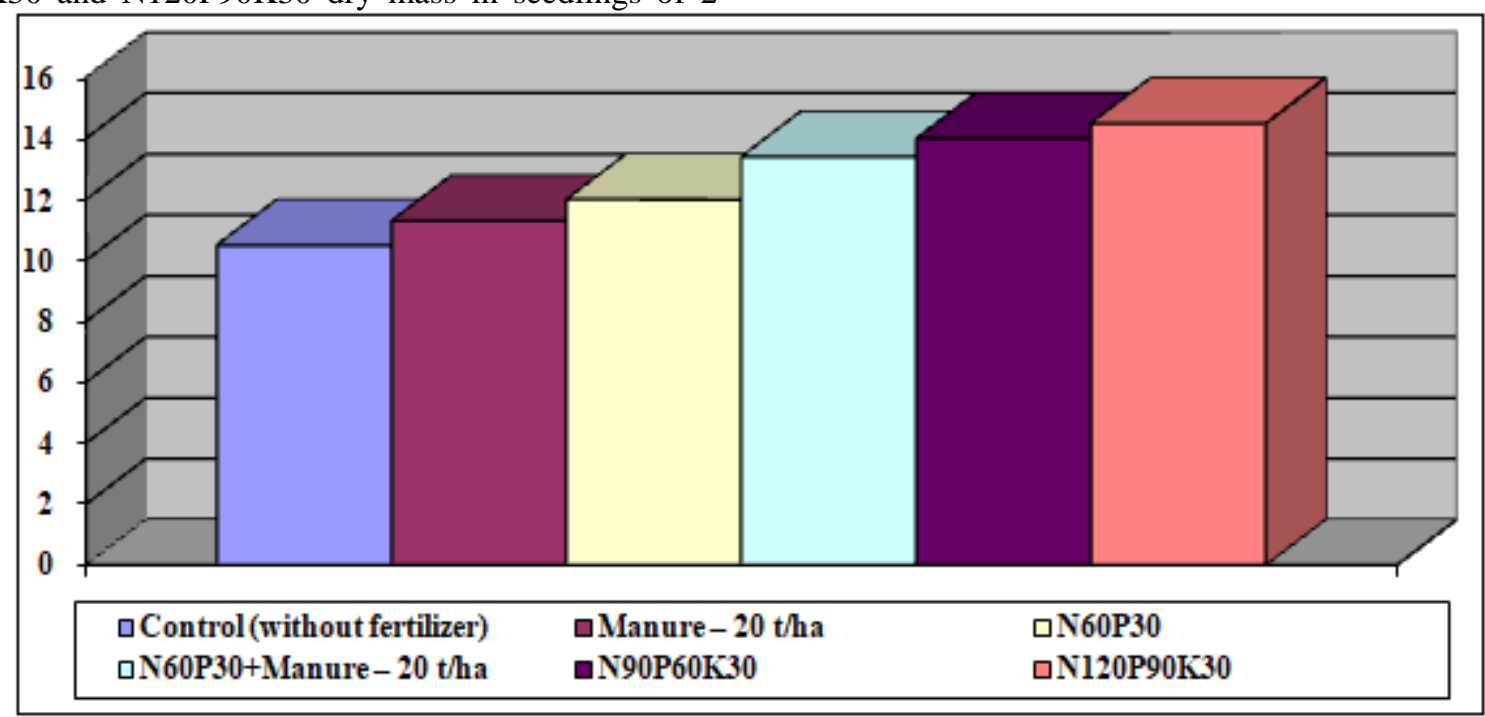

Figure 2: The influence of organo-mineral fertilizers on growth of the height of 2-year-old Scotch pine seedlings, $\mathrm{cm}$

In variants, where fertilizers were fully added output of 2 years old Scotch pine was also better (table 3).

For example, in variants N90P60K30 and N120P90K30 seedlings output made $1670-1770$ th. un. per ha. And from control one -1220 th. un. Thus, standard seedlings made
$470-520$ th. un. And in control one only 270 th. un. In variants, where manure was added together with mineral fertilizers output of standard seedlings was considerably high.

\section{Volume 6 Issue 12, December 2017} www.ijsr.net 


\section{International Journal of Science and Research (IJSR) \\ ISSN (Online): 2319-7064 \\ Index Copernicus Value (2016): 79.57 | Impact Factor (2015): 6.391}

Table 3: The influence of organomineral fertilizers on mass and output of seedlings of 2 years old Scotch pine

\begin{tabular}{|c|c|c|c|c|c|c|c|c|}
\hline \multirow{2}{*}{ Variants } & \multicolumn{2}{|c|}{ Height } & Diameter of & \multicolumn{2}{c|}{ Length of root } & \multicolumn{2}{|c|}{ Dry mass } & Degree of reliability \\
& $\mathrm{cm}$ & $\%$ & root neck, $\mathrm{cm}$ & $\mathrm{cm}$ & $\%$ & gr & $\%$ & of experiment, $\%$ \\
\hline Control(without fertilizer) & $5,07 \pm 0,13$ & 100 & 0,10 & $16,3 \pm 0,64$ & 100 & 3,45 & 100 & 2,6 \\
\hline Manure $-20 \mathrm{t} / \mathrm{ha}$ & $6,22 \pm 0,23$ & 122,6 & 0,10 & $17,8 \pm 1,0$ & 109,1 & 5,15 & 149,2 & 3,8 \\
\hline $\mathrm{N}_{60} \mathrm{P}_{30}$ & $5,90 \pm 0,17$ & 116,4 & 0,11 & $16,3 \pm 0,64$ & 100 & 4,99 & 144,6 & 2,9 \\
\hline $\mathrm{N}_{60} \mathrm{P}_{30}+$ manure $_{20}$ t/ha & $6,70 \pm 0,16$ & 132,1 & 0,12 & $16,0 \pm 0,67$ & 100 & 6,40 & 185,5 & 2,4 \\
\hline $\mathrm{N}_{90} \mathrm{P}_{60} \mathrm{~K}_{30}$ & $6,30 \pm 0,13$ & 124,1 & 0,13 & $16,0 \pm 0,69$ & 100 & 7,55 & 218,8 & 3,6 \\
\hline $\mathrm{N}_{120} \mathrm{P}_{90} \mathrm{~K}_{30}$ & $7,00 \pm 0,30$ & & & $17,5 \pm 0,70$ & & 8,20 & & 3,0 \\
\hline
\end{tabular}

\section{Conclusions}

Obtained information gave an opportunity for definition rules of feeding by nutrients in growing of Scotch pine seedlings and serve as a basis for working out of recommendations on application of fertilizers system. Main fertilizer is put in into soil during its tilling on the depth of $20-25 \mathrm{sm}$ in the norm of $90 \mathrm{~kg} / \mathrm{ha}$ phosphorus and $30 \mathrm{~kg} /$ ha potassium.

In 1 year old plants nourishing is conducted by $\mathrm{N}$ and $\mathrm{P}$ each in the norm of $30 \mathrm{~kg} / \mathrm{ha}$, after appearing seedlings. Second feeding by nitrogen in the norm of $30 \mathrm{~kg} /$ ha is carried out at the end of July, during intensive growth of plants.

In 2 years old plants nourishing is conducted in the same way, $\mathrm{N}$ and $\mathrm{P}$ are put in at the beginning of needles coming out and during intensive growth of plants.

\section{References}

[1] Zheltikova T.A. Working out of norms and terms of mineral fertilizers application in irrigated forest nurseries of Central Asia. Scientific report on the theme №5404 during 1961 - 1965, Tashkent, 1966.

[2] Kozhahmetov S.K. Scientific report of Uz.SRIF during 1991-1995 on theme: "Substantiate mineral fertilizers application in forest nurseries of Priaral with the purpose of improving their productivity.' Tashkent, 1995. 